\title{
Syncuaria squamata (Linstow, 1883) (Nematoda: Acuariidae) in the Great Cormorant [Phalacrocorax carbo sinensins (Blumenbach, 1798)] in northern Poland
}

\author{
G. KANAREK, L. ROLBIECKI
}

University of Gdańsk, Department of Invertebrate Zoology, Al. Marsz. Piłsudskiego 46, 81-378 Gdynia, Poland, E-mail: kanarek@sat.ocean.univ.gda.pl

\begin{abstract}
Summary
Of the 105 great cormorants (Phalacrocorax carbo sinensins) from northern Poland (the Vistula Lagoon and Masurian Lake District), examined in 2000 - 2001, 67 proved hosts of the nematode Syncuaria squamata (Linstow, 1883). The prevalence, mean intensity, and intensity range amounted to $63.8 \%, 36.2$ specimens, and $1-120$ specimens, respectively. The infection was heavier in the immature birds $(84.6 \%, 40.9$ inds, and $1-120$ inds) than in the adults $(3.7 \%, 1$ ind.). The nematodes were dominated by gravid females $(n=1846)$, followed by males $(n=157)$, immature females $(n=79)$, and L4 larvae $(n=2)$. Measurements of the parasite are provided. $S$. squamata is a new species for the parasite fauna of Poland.
\end{abstract}

Key words: Syncuaria squamata; Nematoda; Great Cormorant; Phalacrocorax carbo sinensis; Gulf of Gdańsk; Vistula Lagoon; Mazurian Lakeland; Poland

\section{Introduction}

Since the mid-1980s, the European population of the great cormorant (Phalacrocorax carbo sinensis (Blumenbach, 1798)) has been observed to increase in size (Stempniewicz et al., 1998). At present, Poland boasts Europe's largest great cormorant population, but, so far, data on the nematofauna composition in cormorants in Poland have been limited to two species only: Baruscapillaria carbonis (Dubinin et Dubinina, 1940) and Contracaecum rudolphii Hartwich, 1964 (Okulewicz 1989, 1997; Żuchowska 2000; Kanarek et al., 2002). Syncuaria squamata found in this study is a new species for the fauna of Poland.

\section{Materials and Methods}

In the breeding season 2000, 52 immature great cormorants (27 nestling chicks aged $1-6$ weeks and 25 post-nestling chicks ranging in age from birds older than 6 weeks to tho- se ready to leave the nest) from the breeding colony (Katy Rybackie) located on the Vistula Spit and from the Vistula Lagoon area were examined. In 2001, 26 immature specimens (12 nestling chicks and 14 post-nestling chicks) were subjected to examination as well. The weak gonad development made sexing of those birds impossible. Some of the birds had fell out of the nests or fell down on the ground together with their nests. Live birds were put to sleep with chloroform as described by Dubinina (1971). In addition, 12 sexually mature specimens $(4$ 오, 8 ๙ึ) were examined. The adults were found dead on the Vistula Spit or in fishing nets in the Vistula Lagoon. In August

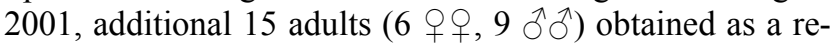
sult of culling of a population inhabiting the Lake Selment Wielki near Ełk (Masurian Lake District) (Fig. 1) were also examined.

Helminthological examination was performed according to the generally adopted techniques (Dubinina, 1971). The nematodes found, isolated from the stomachs and cleaned of food remains, were fixed in 19:1 mixture of glacial acetic acid and $40 \%$ formalin and kept in $70 \%$ ethanol. For identification, the parasites were cleared in lactophenol or glycerol. The nematodes were measured with a measuring eyepiece of the microscope and returned to ethanol.

\section{Results}

Stomachs of 67 great cormorants were found to contain a total of 2084 Syncuaria squamata specimens. Nematodes were found only in the Vistula Spit cormorants, except for a single specimens (an immature female) occurring in a cormorant from the Masurian Lake District. The general extent of infection can be expressed as $63.8 \%$ prevalence, mean intensity of 36.2 specimens, and intensity range of 1 - 120 specimens. In 2000, the infection rate was reflected by $84.6 \%, 33.2$ inds, and $1-120$ inds, the respective data revealed in 2001 being $84.6 \%, 19$ inds, and $1-56$ inds. 


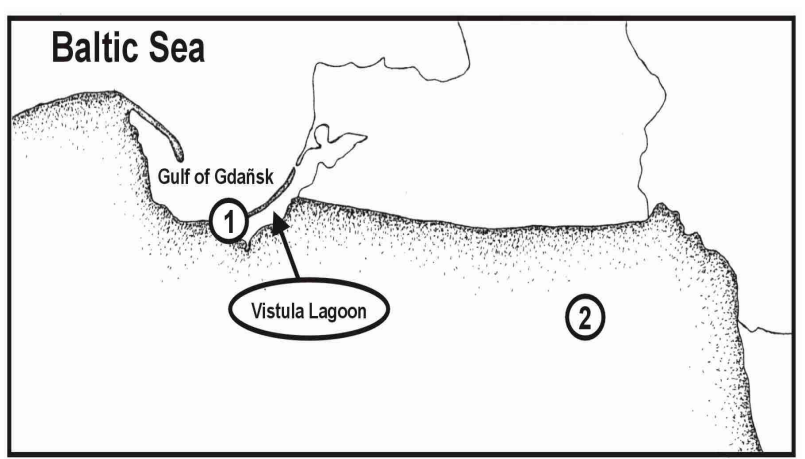

Fig. 1. Map of sampling stations, 1: Breeding colony in Kąty Rybackie, 2: Lake Selment Wielki

The immature birds proved to be much more strongly affected $(84.6 \%, 40.9$ inds, $1-120$ inds) than the adults $(3.7 \%, 1$ ind.). The prevalence was similar in the nestling chicks and post-nestling chicks, but the intensity was clearly higher in the latter (Table 1). The nematodes were dominated by gravid females $(\mathrm{n}=1845)$, followed by males $(n=157)$, immature females $(n=79)$, and L4 larvae $(n=2)$. Most of the gravid females were found in the nestling chicks (Table 2). width $0.019-0.039(0.027)$. Vulva-anus distance $0.22-$ 0.39 (0.26); tail length $0.08-0.19(0.11)$. Deirid length $0.042-0.065$ (0.051); deirid width $0.042-0.065$ (0.052). Muscular pharynx length $0.41-0.55(0.44)$; glandular pharynx length $0.84-1.17$ (1.00). Nerve ring-anterior body end distance $0.45-0.64(0.58)$.

Immature females $(n=17)$ : body length $5.84-10.61(8.17)$; maximum body width $0.19-0.34(0.27)$. Cordon length $0.66-0.96$ (0.81). Deirid length $0.023-0.046$ (0.031); deirid width $0.026-0.038$ (0.031). Vulva-anus distance $0.099-0.15(0.13)$. Muscular pharynx length $0.13-0.24$ (0.18); glandular pharynx length $0.33-0.49(0.39)$. Nerve ring-anterior body end distance $0.17-0.21(0.19)$.

L4 larva (female, $\mathrm{n}=1$ ): body length 2.53 ; maximum body width: 0.16 . Cordon length 0.31 ; distance between anterior body length and the characteristic bipartite deirid 0.47 . Deirid length 0.0056; deirid width 0.0037 . Nerve ring-anterior body end distance 0.15. Deirid-cordon distance 0.096 . Muscular pharynx length 0.0103 ; glandular pharynx length 0.0207 . Tail length 0.079 .

\section{Discussion}

The nematode genus Syncuaria is represented by 9 valid

Tab. 1. Prevalence (\%), mean intensity (ind.) and range of intensity (ind.) of Syncuaria squamata in the cormorant from the Vistula Lagoon and Mazurian Lakeland

\begin{tabular}{lccc}
\hline & Nestling chicks & Post-nestling chicks & Adult \\
\hline Vistula Lagoon & $87.2 / 22.7 / 1-93$ & $82 / 40.1 / 2-120$ & 0 \\
Masurian Lakeland & - & - & $6.6 / 1 / 1$ \\
Total & $87.2 / 22.7 / 1-93$ & $82 / 40.1 / 2-120$ & $3.7 / 1 / 1$ \\
\hline
\end{tabular}

- - not examined; 0 - not found

Tab. 2. Population structure (prevalence, mean intensity, range of intensity) of Syncuaria squamata in the great cormorant in the Vistula Lagoon and the Masurian Lake District

\begin{tabular}{lccc}
\hline \hline Nematode & Cormoran & Nestling chicks & Post-nestling chicks \\
\hline Males $(\mathrm{n}=157)$ & $46.9 / 3.7 / 1-8$ & $65.6 / 4.8 / 1-25$ & 0 \\
Gravid females $(\mathrm{n}=1846)$ & $100 / 21.2 / 1-86$ & $100 / 36.4 / 1-109$ & 0 \\
Immature females $(\mathrm{n}=79)$ & $50 / 3 / 1-11$ & $46.9 / 2.7 / 1-9$ & $3.7 / 1 / 1$ \\
Larvae L4 $(\mathrm{n}=2)$ & 0 & $3.1 / 2 / 2$ & 0 \\
\hline
\end{tabular}

Description (measurements in millimetres):

Male ( $n=17$ ): body length $5.76-10.13$ (mean of 7.63 ); maximum width $0.20-0.31(0.22)$. Cordon length $0.77-$ 1.33 (1.03). Deirid length $0.023-0.042$ (0.032); deirid width $0.019-0.030(0.025)$. Muscular pharynx length 0.17 $-0.29(0.25)$; glandular pharynx length $0.36-0.48(0.42)$. Nerve ring-anterior body end distance $0.16-0.28(0.26)$. Longer spicule length $1.03-1.49$ (1.20); shorter spicule length $0.13-0.20(0.16)$.

Gravid females $(n=26)$ : body length 17.6 - 34.1 (27.4); maximum body width $0.55-0.86(0.69)$. Cordon length $0.83-1.56$ (1.23). Egg length $0.029-0.058$ (0.040); egg species occurring world-wide in birds from the families Podicipedidae, Phalacrocoracidae, and Ciconidae (Wong et $a l ., 1986)$. One of those species, namely $S$. squamata, is regarded as specific for the cormorants Phalacrocorax carbo (L., 1758), P. auritus (Lesson, 1831), and P. pygmaeus Pall., 1773 (Baruš et al., 1978; Wong et al., 1986; Anderson, 1992). So far, only $S$. decorata (Cram, 1927) (reported as Decorataria decorata) has been recorded in Poland from the little grebe (Podiceps ruficollis) and the great crested grebe (P. cristatus) (Okulewicz, 1980, 1997). Syncuaria squamata found in this study expands the list of nematode species known from Poland. 
Although the size of the nematodes found was similar to that reported by Baruš et al. (1978), Moravec (1990), Wong et al. (1986), and Wong and Anderson (1987), the ranges of both length and width were wider, which could have resulted from a higher number of the parasites measured in this study.

The level of infection observed $(63.8 \%, 36.2$ inds, $1-120$ inds) should be considered high. For example, 3 out of the 10 Bohemian cormorants studied by Moravec (1990) proved infected and yielded a total of 12 nematodes. Dezfuli et al. (2002), who studied cormorants in Italy, reported infection at the level of $21 \%, 2.3$ inds, and $1-10$ inds. The 5-week-old Canadian double-crested cormorants (Phalacrocorax auritus auritus) examined by Wong and Anderson (1987) showed the extent of infection to amount to $93 \%, 17$ inds, and $2-46$ inds.

It is worth mentioning that the high infection parameters found in the great cormorant of the Katy Rybackie breeding colony may be indicative of intensive reproduction of the parasite in the adjacent brackish waters of the Vistula Lagoon and Gulf of Gdańsk of salinities averaging 2.4 and 7.5 PSU, respectively (Lomniewski, 1958; Majewski, 1990). As reported by numerous authors (e.g., Stempniewicz \& Grochowski, 1997; Bzoma et al., 2003), the colony members feed in the Lagoon and in the Gulf; moreover, there are no major freshwater reservoirs in the colony's vicinity.

A relationship between the presence of Syncuaria squamata and the cormorant age may provide interesting insights. Apart from a single nematode found in an adult bird, all the parasites were removed from immature cormorants. It is, however, difficult to assess the data provided by other authors who seldom, if at all, reported age categories of the birds they examined or based their studies on artificial infection. When trying to identify causes of the higher infection rate in the immature birds, one has to first rule out a possibility that the parents (adults) of the birds "avoid" infected fish or are not exposed to them due to different food preferences. It is worth mentioning that, like adults, immature cormorants are typical piscivores, fed fish by the parents from their first day out of an egg. As opposed to some birds (e.g., the seagulls), the cormorants do not experience an ontogenetic dietary switch, therefore the food composition is virtually identical in the immature and adult birds. For this reason, both the young and the adult cormorants are exposed to identical invasive forms of parasites occurring in their food. Consequently, the presence of most $S$. squamata in the immature birds is most likely a result of a much higher food uptake (related to high energy demand) by the immature birds during growth (Sitko, 1993) or the deficiency of their incompletely developed immunological system (Ros et al., 1997; Sol et al., 2003), or a combination of the two factors. However, effects of other environmental variables cannot be excluded. Moreover, a high density of the great cormorants at their breeding sites may play a role as well by rapidly increasing the abundance of larval stages of the parasite, supported by intermediate (ostracods) and paratenic hosts (fish), as discussed by, i.a.,
Jensen et al. (1994) and Mitgaard et al. (2003). It has to be added that during the period of study, in 2000, the Vistula Spit breeding colony consisted of 7995 breeding pairs; there were 8670 pairs in 2001 and as many as 11495 pairs in 2004, making the colony the Europe's largest (Goc et al., 2005).

The structure of the great cormorant-supported S. squamata population is an additional question. Among the four developmental studies found, gravid females were dominant. They dominated both in the nestling chicks and in the postnestling chicks. Wong and Anderson (1987), who examined much fewer birds, found the naturally infected doublecrested cormorants to support mostly mature males, followed by immature females, gravid females, and the L4 larvae. From the age of 8 weeks on, the birds supported primarily males, the younger birds being affected mostly by immature females; those birds older than 15 weeks were usually hosting males only. The artificially infected doublecrested cormorants examined in week $12.5-22.4$ showed a slight domination of gravid females. With respect to the data obtained, it is worth stressing that the great prevalence of nematode females, particularly the gravid ones, is advantageous from the standpoint of the species' persistence in the ecosystem.

\section{Acknowledgements}

The authors wish to extend their sincere thanks to Prof. V. Baruš of the Institute of Vertebrate Biology, CAS, Brno (Czech Republic) for his help in nematode identification. The research was supported in part by the Polish Scientific Research Committee grant No. 2PO4C 07027.

\section{References}

ANDERSON, R. C. (1992): Nematode parasites of vertebrates. Their development and transsmision. C. A. B. International, Wallingford, Oxon (U. K.)

BArUš, V., SERGEeVA, T. P., Sonin, M. D., RYZHIKOV, K. V. (1978): Helminths of fish-eating birds of the Palearctic region. Vol. I Nematoda. USSR Academy of Sciences/ Czechoslovak Academy of Sciences; Moscow / Prague

Bzoma, S., Goc, M., BRYlski, T., SteMPNIEWICZ, L., ILISZKO, L. (2003): Seasonal changes and intra-colony differentation in the exploitation of two feeding grounds by Great Cormorants Phalacrocorax carbo sinensis breeding at Katy Rybackie (N Poland). Vogelvelt 124 (Suppl.): 175 $-181$

Dezfuli, B. S., Volponi, S., Beltrami, I., Poulin, R. (2002): Intra- and interspecific density-dependent effects on growth in helminth parasites of the cormorant, Phalacrocorax carbo sinensis. Parasitology 124: 537 - 544

DuBININA, M. N. (1971): Parasitological investigations of birds. Izdatelstvo Nauka, Leningrad

Goc, M., IliszKo, L., StempNiEwicz, L. (2005). The largest European colony of the Great Cormorant on the Vistula Spit (N Poland) - an impact on the forest ecosystem. Ecol. Quest. 6: in press 
Jensen, T., Andersen, K., Des Clers, S. (1994): Sealworm (Pseudoterranova decipiens) infections in demersal fish from two areas in Norway. Can. J. Zool., 72: 598 608

KANAREK, G., RolbieCKi, L., SitKO, J., BARUŠ, V., ROKICKI, J. (2002): The occurrence of Contracaecum rudolphi Hartwig, 1964 in the cormorant (Phalacrocorax carbo sinensis) in northern Poland. Slovak and Czech Helminthological Days, 28 - 31 May 2002, Stará Lesná, Slovak Republic: 22 ŁoMNIEWSKI, K. (1958): Vistula Lagoon. Prace geograficzne 15. PAN, Warszawa (in Polish)

MAJEWSKI, A. (1990): Gulf of Gdańsk. Wydawnictwo Geologiczne, Warszawa (in Polish)

MitgaArd, T., Andersen, K., Halvorsen, O. (2003): Population dynamics of sealworm, Pseudoteranowa decipiens sensu lato, in sculpins, Myoxocephalus scorpius, from two areas in Norway between 1990 and 1996. Parasitol. Res., 89: $387-392$

MORAVEC, F. (1990): First record of the nematode Syncuaria sqamata (Linstow, 1883) from common cormorant (Phalacrocorax carbo (L.)) in Czechoslovakia. Folia Parasitol., 37: 365 - 366

OKULEWICZ, A. (1980): The occurrence of nematode Decorataria decorata (Cram, 1927) Skrjabin, Sobolev et Ivaskhin, 1965 in Podiceps ruficolis (Pall., 1764) and Podiceps cristatus (L., 1758) in Poland. Wiad. Parazytol., 26: $721-733$

OKulEwiCZ, A. (1989): A redescription of Capillaria carbonis (Rudolphi, 1819), (Capillariidae), based on material collected from the cormorant (Phalacrocorax carbo). Wiad. Parazytol., 35: $577-583$
OKulewicz, A. (1997): Catalog of polish fauna. Vol. 4, Parasites of Aves, Nematoda. Polskie Towarzystwo Parazytologiczne, Warszawa

Ros, F. H. A., Groothius ,T. G. G., Apanius, V. (1997): The relation among gonadal steroids, immunocompetence, body mass, and behaviour in young Black-Headed Gulls (Larus ridibundus). Am. Nat., 150: $201-219$

SiTKO, J. (1993): Ecological relations of trematodes infecting lariform birds in Czech Republic. Acta Sci. Nat. Acad. Sci. Bohemoslov. Brno. 27: $1-98$

Sol, D., Jovani, R., Torres, J. (2003): Parasite mediated mortality and host immune response explain age-related differences in blood parasitism in birds. Oecologia, 135: $542-547$

StempniewiCZ, L., Grochowski, A. (1997): Diet composition of Cormorants in the breeding colony of Katy Rybackie, NE Poland (regurgitated preys, 1992 - 1994). Suppl. Ric. Biol. Selvaggina. 26: 537 - 544

STEMPNIEWICZ, L., GOC, M., NITECKI, C. (1998): The need to conduct ecological studies on the Cormorant Phalacrocorax carbo in Poland. Notatki Ornitol., 39: 33 - 45

Wong, P. L., Anderson, R. C. (1987): Development of Syncuaria sqamata (Linstow, 1883) (Nematoda; Acuarioidea) in ostracods (Ostracoda) and double-crested cormorants (Phalacrocorax auritus auritus). Can. J. Zool., 65: $2524-2531$

Wong, P. L., Anderson, R. C., BArtlett, C. M. (1986): Revision of the genus Syncuaria Gilbert, 1927 (Nematoda: Acuarioidea). Can. J. Zool., 64: 1186 - 1196

ŻUCHOWSKA, E. (2000): Contracaecum rudolphii Hartwich, 1964 (Nematoda: Anisakidae) in the Great Cormorants in Poland. Wiad. Parazytol., 46: $411-412$ 